Agronomic efficiency of phosphorus at different base saturation in soybean yield in

\title{
Cerrado soils
}

Eficiência agronômica do fósforo em diferentes saturações por bases na produtividade da soja em solos de Cerrado

Eficiencia agronómica del fósforo a diferentes saturaciones de bases en el rendimiento de soja en suelos del Cerrado

Received: 11/18/2020 | Reviewed: 11/29/2020 | Accept: 12/01/2020 | Published: 12/05/2020

Rosilene de Morais da Silva

ORCID: https://orcid.org/0000-0001-6127-4310

Universidade Federal do Piaui, Brasil

E-mail: rosilenemorais7@ hotmail.com

Antônio Veimar da Silva

ORCID: https://orcid.org/0000-0003-2080-0307

Universidade Federal da Paraiba, Brasil

E-mail: veimar26@hotmail.com

João Carlos Medeiros

ORCID: https://orcid.org/0000-0001-7745-7015

Universidade Federal do Sul da Bahia, Brasil

E-mail: joaomedeiros@ufsb.edu.br

Artur Mendes Medeiros

ORCID: https://orcid.org/0000-0001-8415-4565

Universidade Federal do Piauí, Brasil

E-mail: artur.medeiros@ufpu.edu.br

Erick Almeida Andrade https://orcid.org/0000-0003-0497-3195

Universidade Federal do Piauí, Brasil

E-mail: erick-andrade10@ hotmail.com

Carla Michelle da Silva

ORCID: https://orcid.org/0000-0002-1872-5902

Universidade Federal de Viçosa, Brasil

E-mail: carla.mic@hotmail.com 
Marina Silveira Batista

ORCID: https:// orcid.org/0000-0001-5663-8706

Universidade Federal do Piauí, Brasil

E-mail: marina_silveira21@yahoo.com.br

Fábio Mielezrski

ORCID: https://orcid.org/0000-0003-3409-2479

Universidade Federal da Paraíba, Brasil

E-mail: mfabioagro@hotmail.com

\begin{abstract}
This study aimed to evaluate the agronomic efficiency of phosphorus at different soil base saturation in soybean production. Two experiments were conducted (greenhouse and field) in the 2016/2017 growing season in a DBC experimental design, with a factorial arrangement 3 (base saturation) x 4 (phosphorus levels), with four replications. Number of pods per plant (NVP), number of grains per plant (NGP), first pod height (A1V), number of grains per pod (NGV), one thousand grain weight (PMG) and yield (PROD) were evaluated. In the greenhouse experiment, there was a significant difference for the interaction SxP (base saturation $\mathrm{x}$ phosphorus levels) for the variables NVP, NGP and yield, and for the field experiment, only the yield was significant. For the base saturation, only the A1V was significant and for the phosphorus, only the NVP had a significant effect. Phosphorus fertilization in Cerrado soils increases soybean yield and has an agronomic efficiency of 14.59 $\mathrm{kg}$ in soils with $50 \%$ base saturation and $12.87 \mathrm{~kg}$ soybean grains per kilogram of phosphorus applied in soils with base saturation at $70 \%$, within high yield standards.
\end{abstract}

Keywords: Limestone; Phosphate fertilizer; Yield components; Glycine max; Cerrado; Greenhouse x Field.

\title{
Resumo
}

Este trabalho teve como objetivo avaliar a eficiência agronômica do fósforo em diferentes níveis de saturação por bases do solo na produção de soja. Foram conduzidos dois experimentos (casa de vegetação e campo) na safra 2016/2017 em delineamento experimental DBC, com arranjo fatorial 3 (saturação por bases) x 4 (níveis de fósforo), com quatro repetições. Foram avaliados o número de vagens por planta (NVP), número de grãos por planta (NGP), altura da primeira vagem (A1V), número de grãos por vagem (NGV), peso de mil grãos (PMG) e produtividade (PROD). No experimento em casa de vegetação, houve 
diferença significativa para a interação SxP (saturação por bases x níveis de fósforo) para as variáveis NVP, NGP e produtividade, e para o experimento em campo, apenas a produtividade foi significativa. Para a saturação de bases, apenas o A1V foi significativo e para o fósforo, apenas o NVP teve efeito significativo. A fertilização com fósforo em solos de Cerrado aumenta a produtividade da soja e tem uma eficiência agronômica de $14,59 \mathrm{~kg}$ em solos com $50 \%$ de saturação por bases e $12,87 \mathrm{~kg}$ de grãos de soja por quilograma de fósforo aplicado em solos com saturação por bases de $70 \%$, dentro de padrões de alto rendimento.

Palavras-chave: Limestone; Fertilizante fosfatado; Componentes de rendimento; Glycine max; Cerrado; Estufa x Campo.

\section{Resumen}

Este estudio tuvo como objetivo evaluar la eficiencia agronómica del fósforo a diferentes saturaciones de bases del suelo en la producción de soja. Se realizaron dos experimentos (invernadero y campo) en la temporada de crecimiento 2016/2017 en un diseño experimental DBC, con arreglo factorial 3 (saturación de bases) x 4 (niveles de fósforo), con cuatro repeticiones. Se evaluó el número de vainas por planta (NVP), el número de granos por planta (NGP), la altura de la primera vaina (A1V), el número de granos por vaina (NGV), el peso de mil granos (PMG) y el rendimiento (PROD). En el experimento de invernadero, hubo una diferencia significativa para la interacción SxP (saturación de bases x niveles de fósforo) para las variables NVP, NGP y rendimiento, y para el experimento de campo, solo el rendimiento fue significativo. Para la saturación de bases, solo el A1V fue significativo y para el fósforo, solo el NVP tuvo un efecto significativo. La fertilización con fósforo en suelos del Cerrado aumenta el rendimiento de la soja y tiene una eficiencia agronómica de 14,59 $\mathrm{kg}$ en suelos con $50 \%$ de saturación de bases y $12,87 \mathrm{~kg}$ de granos de soja por kilogramo de fósforo aplicado en suelos con saturación de bases al 70\%, dentro de estándares de alto rendimiento.

Palabras clave: Piedra caliza; Fertilizante de fosfato; Componentes de rendimiento; Glycine max; Cerrado; Invernadero x campo.

\section{Introduction}

Soybean [Glycine $\max$ (L.) Merr.] is a crop with high capacity to grow in varied soils and climates, which make it a versatile crop and one of the most widely grown in the world (Loman and Ju). This occurs mainly in large-scale commercial systems such as the USA, 
Brazil, Argentina, China and India (FAO, 2016). It is cultivated throughout Brazil and is one of the most important crops for export, as well as for national consumption.

The Cerrado biome region is a leader in soybean production in Brazil (Dall'Agnol, 2016), however its soils are highly weathered, which is generally characterized by low nutrient availability to plants (Silva et al., 2015). Soil quality is one of the important aspects to consider when increasing yields (Amaral et al., 217).

Soil management by correcting acidity and providing adequate nutrient levels (França Neto et al., 2016), is one of the factors that ensure soybean production in this region of Brazil. Another important factor is that field applied limestone provide higher leaf contents of $\mathrm{N}, \mathrm{P}$ and Ca (Broch and Ranno, 2012), causing an increase in yield, probably due to an increase in $\mathrm{Ca}^{2+}$ and $\mathrm{Mg}^{2+}$ contents (Zandora et al., 2015).

Among the essential nutrients for soybean cultivation, phosphorus $(\mathrm{P})$ is limiting for growth and indispensable in several physiological factors and biochemical processes (Simpson et al., 2015; Wang et al., 2014). It is essential in cell division, participates in shoot and root system growth, as well as reproduction and plant metabolism (photosynthesis, respiration and compound synthesis) (Taiz et al., 2017).

Nutrient efficiency is measured by the ratio of yield to applied inputs, i.e. amount of dry matter or number of grains produced per unit of applied nutrient (Fageria, 2001). This can be affected by soil properties, phosphate sources, modes of application and plant species (Chien and Menon, 1995).

In Cerrado soils, in particular, it can also be facilitated by liming, because it is considered as one of the practices that contributes most to increase soybean productivity (Zandona et al., 2015), as it increases the base saturation, reduces adsorption/precipitation of $\mathrm{P}$ in soil, increasing its availability for plant absorption, corrects soil acidity, provides calcium and magnesium, and neutralizes aluminum phytotoxicity in the soil (Bambolim et al., 2015).

Adequate phosphorus supply is also of great importance for good soybean yield (França Net et al., 2016). This is because with increasing $\mathrm{P}$ levels in plant nutrition, $\mathrm{P}$ accumulation also increases in different parts of the plant (Trevizam et al., 2013).

Given the possibility of achieving greater gains in soybean production, this study aimed to evaluate the agronomic efficiency of phosphorus in different base saturations in soybean yield. 


\section{Methodology}

\subsection{Study area}

Two experiments were carried out, both in the 2016/2017 growing season, with soybean cultivar FTR 1186 IPRO, indeterminate growth habit, 130-day cycle and maturity group 8.6. The experiments (greenhouse and field) were conducted in the experimental area at the Federal University of Piaui - UFPI, Campus Professor Cinobelina Elvas, in Bom Jesus, State of Piauí, Brazil. The area is located at coordinates 0904'46.3 "S, 44¹9'37,5" W, with average elevation of $282 \mathrm{~m}$. The climate according to the Köppen classification is Aw, hot and humid with an average temperature around $24^{\circ} \mathrm{C}$. The average annual rainfall is around $1,100 \mathrm{~mm}$, concentrated from November to March. Climatic data were collected from the UFPI weather station during the experiment, as shown in Figure 1.

Figure 1. Climate data in Bom Jesus, State of Piauí, 2017, in the experimental period.
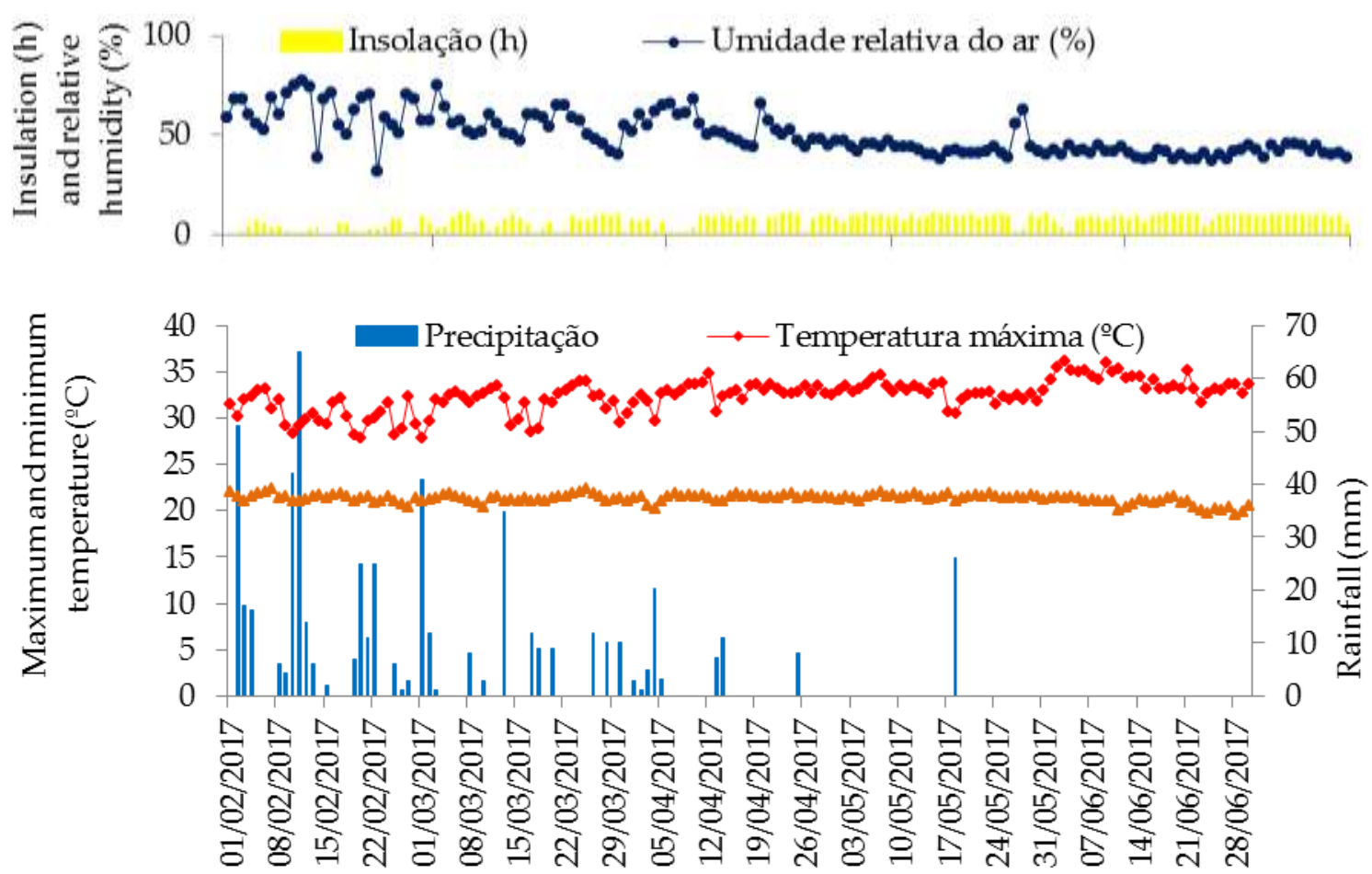

Fonte: Dados da pesquisa, UFPI, Bom Jesus - PI.

\subsubsection{Experiment 01}

The experiment was carried out in a greenhouse in plastic pots with capacity for $14 \mathrm{~kg}$ soil. The soil used was collected from the 0-20 cm layer in a Cerrado area in Bom Jesus, State 
(CC BY 4.0) | ISSN 2525-3409 | DOI: http://dx.doi.org/10.33448/rsd-v9i11.10389

of Piauí. After collection, the soil was homogenized, sieved and subjected to chemical analysis, and according to the results in Table 1, 60 days before sowing, it was applied dolomitic limestone with $88 \%$ PRNT in different amounts, $0.464 \mathrm{~g} / \mathrm{plot}$ and 928g/plot, (each plot was represented by 12 pots, totaling 48 pots), in order to obtain three base saturation values 50,60 and $70 \%$ respectively.

Table 1. Chemical characterization of soil (experiment 01) in the greenhouse. Bom Jesus, 2017.

\begin{tabular}{llllllllll}
\hline $\mathbf{p H}$ & $\mathbf{H}+\mathbf{A l}$ & $\mathbf{A l}$ & $\mathbf{C a}$ & $\mathbf{M g}$ & $\mathbf{K}$ & $\mathbf{S B}$ & $\mathbf{T}$ & $\mathbf{P}$ & $\mathbf{K}$ \\
\hline \multicolumn{2}{c}{$\mathrm{H}_{2} \mathrm{O}$} \\
5.3 & 3.30 & 0 & 2.32 & 0.67 & 0.33 & 3.32 & 6.62 & 2.9 & 130.1 \\
\hline $\mathbf{C u}$ & $\mathbf{F e}$ & $\mathbf{M n}$ & $\mathbf{Z n}$ & $\mathbf{V}$ & $\mathbf{m}$ & $\mathbf{O M}$ & $\mathbf{C l a y}$ & Silt & Sand \\
\hline & $\mathrm{mg} \mathrm{dm}^{-3}$ & \multicolumn{2}{c}{$\%$} & & $\%$ & & & $\mathrm{~g} / \mathrm{kg}$ & \\
\hline 1.35 & 275.13 & 302.45 & 3.98 & 50.2 & 0 & 12.03 & 162 & 758 & 80 \\
\hline
\end{tabular}

Fonte: Research data, Laboratory of UFPI, Bom Jesus - PI.

Shortly before sowing, phosphate was applied individually in each pot, using four phosphorus levels: dose recommended by soil analysis (3.99g/pot - here called 1.0$), 25 \%$ above the recommended dose. (4.89g/pot - here called 1.25) and 50\% above the recommended dose (5.98g/pot - here called 1.5), and the control ( $0 \%$ phosphorus), the source of phosphorus used was single superphosphate. Five soybean seeds were sown in each pot, and after thinning only three seedlings were left in each pot.

\subsubsection{Experiment 02}

The experiment was implemented in the field in January 2017. Soil samples for chemical and physical analysis (Table 2) was taken by sampling in the $0-0.20$ m layer. 
Research, Society and Development, v. 9, n. 11, e83191110389, 2020

(CC BY 4.0) | ISSN 2525-3409 | DOI: http://dx.doi.org/10.33448/rsd-v9i11.10389

Table 2. Chemical characterization of soil in experiment 02 (Field). Bom Jesus, 2017.

\begin{tabular}{cccccccccc}
\hline $\mathbf{p H}$ & $\mathbf{H}+\mathbf{A l}$ & $\mathbf{A l}$ & $\mathbf{C a}$ & $\mathbf{M g}$ & $\mathbf{K}$ & $\mathbf{S B}$ & $\mathbf{T}$ & $\mathbf{P}$ & $\mathbf{K}$ \\
\hline $\mathrm{H}_{2} \mathrm{O}$ & & $--------------\mathrm{cmolcdm}^{-3}------------$ & & $----\mathrm{mg} \mathrm{dm}^{-3}------$ \\
5.3 & 2.64 & 0 & 1.42 & 0.51 & 0.39 & 2.32 & 4.96 & 15.8 & 150.8 \\
\hline $\mathbf{C u}$ & $\mathbf{F e}$ & $\mathbf{M n}$ & $\mathbf{Z n}$ & $\mathbf{V}$ & $\mathbf{m}$ & $\mathbf{O M}$ & Clay & Silt & Sand \\
\hline & $\mathrm{mg} \mathrm{dm3}$ & & $\%$ & $\%$ & & & $\mathrm{~g} / \mathrm{kg}$ & \\
\hline 0.08 & 76.21 & 12.21 & 3.03 & 49.7 & 0 & 13 & 100 & 173 & 727 \\
\hline
\end{tabular}

Fonte: Research data, Laboratory of UFPI, Bom Jesus - PI.

The soil was prepared by a leveling grid in the whole experimental area, delimited in $432 \mathrm{~m}^{2}$, divided into four blocks, and according to the soil analysis, limestone was applied to obtain three base saturation values, 50,60 and $70 \%$ with the respective levels $(0 ; 9.5 \mathrm{~kg}$; $13.1 \mathrm{~kg}$ limestone/plot), as well as phosphorus levels: Recommended by soil analysis (601.1g/subplot - here called 1.0), $25 \%$ higher than recommended (751.5g/subplot - called here 1.25$)$ and $50 \%$ higher than recommended (901.8g/subplot - called here 1.5) and control$0 \%$.

Limestone was applied 60 days before soybean sowing using 88\% PRNT dolomitic limestone. Phosphate fertilization was performed along with sowing in the furrow using single superphosphate and manual sowing, distributing 18 seeds in the planting row; later thinning was done leaving only 9 plants per row. The experimental unit was represented in $9 \mathrm{~m}^{2}$ consisting of 9 planting rows of 3 meters in length with $0.45 \mathrm{~cm}$ spacing. And the useful area of each plot consisted of the 5 central rows, disregarding the 2 rows of each end.

The experimental design used in both experiments was randomized blocks (DBC), in a factorial arrangement of 3 (base saturation) x 4 (phosphorus levels), with four replications.

Harvest was performed manually and the material was taken to the seed analysis laboratory of the university for the other analyses.

The experiment 01 evaluated the plants of the experimental unit (pot) and in experiment 02,10 plants of the plot useful area were randomly marked for evaluation of crop yield components.

The yield components evaluated in both experiments were:

a) Number of pods per plant: obtained by the ratio of the total number of pods to the total number of plants collected in the useful area of the plot (Petter et al., 2012).

b) Number of grains per plant - the number of grains of each plant is counted, separately, then the average is calculated (Dalchiavon and Carvalho, 2012). 
Research, Society and Development, v. 9, n. 11, e83191110389, 2020

(CC BY 4.0) | ISSN 2525-3409 | DOI: http://dx.doi.org/10.33448/rsd-v9i11.10389

c) Height of the first pod: in $\mathrm{cm}$, measured from the ground level to the lower end of the first pod during the maturation period (Alcântara Neto et al., 2012).

d) Number of grains per pod - determined by the average number of seeds divided by the average number of pods of plants in the useful area of the plot (Zandona et al., 2015).

e) One thousand grain weight - Eight repetitions of 100 grains were separated and weighed. The result is expressed in grams (Brasil, 2009).

f) Yield - used for plants in the useful area (greenhouse and field) and estimated in $\mathrm{kg}$ ha $^{-1}$ (13\% moisture content on a wet basis) (Barbosa et al., 2014).

g) Nutritional efficiency - ratio of total biomass to the amount of nutrient absorbed. It was expressed by the following calculation (Fageria, 1998; Fageria et al., 2014) as follows:

Agronomic Efficiency = production in $\mathrm{kg}$ with fertilization - Production in $\mathrm{kg}$ without fertilization

Amount of nutrient applied in $\mathrm{kg}$

\subsection{Statistical analysis}

Data from field production components and laboratory data were always treated as qualitative and the randomized block analysis of variance was performed in a split plot arrangement, with saturation assigned to plots and phosphorus to subplots. Subsequently, the significance of the interaction was detected and the means were broken down and compared by Tukey's test at 5\% probability.

The results were tested for normality by ShapiroWilk, variance test by F-test $(\mathrm{p}<0.05)$ with the statistical software R 3.6. Quantitative factors (limestone dose and phosphorus level) were analyzed with regression equation adjustments.

\section{Results}

The Cerrado in the State of Piauí has soils with different base saturation, being mostly weathered and nutrient-poor soils. To solve this problem, it is necessary to fertilize the soil so that the crop to be planted can respond in productivity. Finding the agronomic efficiency of fertilizer use at different base saturations is of utmost importance, as it is necessary to increase yield at a lower cost as the application savings become relevant for small, medium and large soybean producers. 
Research, Society and Development, v. 9, n. 11, e83191110389, 2020

(CC BY 4.0) | ISSN 2525-3409 | DOI: http://dx.doi.org/10.33448/rsd-v9i11.10389

The analysis of variance evidenced a significant effect of the interaction Saturation (S) $\mathrm{x}$ Phosphorus P2O5 levels (P) for the variables: number of pods per plant (NVP), number of grains per plant (NGP), and yield (PROD) for the greenhouse experiment and non-significant for the field experiment (Table 3).

Table 3. Summary of analysis of variance for number of pods per plant (NVP), number of grains per plant (NGP), first pod height (A1V), number of grains per pod (NGV), one thousand grain weight (PMG), and yield (PROD).

\begin{tabular}{|c|c|c|c|c|c|c|c|}
\hline \multicolumn{8}{|c|}{ Greenhouse experiment } \\
\hline \multirow{2}{*}{ SV } & \multirow{2}{*}{ DF } & \multicolumn{6}{|c|}{ QM } \\
\hline & & NVP & NGP & A1V (cm) & NGV & PMG & PROD \\
\hline Block & 3 & 37.923 & 64.09 & 2.690 & 0.048 & 182.36 & 0.038 \\
\hline Satur $(S)$ & 2 & $35.8^{\mathrm{ns}}$ & $169.7^{\mathrm{ns}}$ & $35.72^{\mathrm{ns}}$ & $0.053^{\mathrm{ns}}$ & $128.0^{\mathrm{ns}}$ & $0.003^{\mathrm{ns}}$ \\
\hline error a & 6 & 16.118 & 59.96 & 0.980 & 0.014 & 82.0 & 0.070 \\
\hline $\mathrm{P} 2 \mathrm{O} 5(\mathrm{P})$ & 3 & $2006.6^{* * *}$ & $12937^{* *}$ & $3.761^{\mathrm{ns}}$ & $0.061^{\mathrm{ns}}$ & $87.7^{\mathrm{ns}}$ & $4.070^{* *}$ \\
\hline $\mathrm{S} \times \mathrm{P}$ & 6 & $336.3^{* *}$ & $1704^{* *}$ & $2.654^{\mathrm{ns}}$ & $0.035^{\mathrm{ns}}$ & $48.80^{\mathrm{ns}}$ & $0.380^{* *}$ \\
\hline erro $b$ & 27 & 33.53 & 95.29 & 1.813 & 0.017 & 38.67 & 0.035 \\
\hline $\mathrm{CVa} \%$ & & 5.02 & 4.87 & 5.46 & 4.48 & 7.92 & 7.76 \\
\hline $\mathrm{CVb} \%$ & & 7.23 & 6.13 & 7.42 & 4.98 & 5.44 & 5.51 \\
\hline Mean & & 80.04 & 159.1 & 18.14 & 2.650 & 114.4 & 3.401 \\
\hline \multicolumn{8}{|c|}{ Field experiment } \\
\hline Block & 3 & 16.3 & 93.7 & 44.8 & 4.34 & 46.4 & 274658 \\
\hline Satur(S) & 2 & $37.4^{\mathrm{ns}}$ & $215^{\mathrm{ns}}$ & $34.3^{* *}$ & $799^{\mathrm{ns}}$ & $531^{\mathrm{ns}}$ & $3678274^{\mathrm{ns}}$ \\
\hline error a & 6 & 27.1 & 156 & $53.7^{\mathrm{ns}}$ & 14.8 & 67.4 & 191577 \\
\hline $\mathrm{P} 2 \mathrm{O} 5(\mathrm{P})$ & 3 & $26.8^{* *}$ & $154^{\mathrm{ns}}$ & 43.2 & $32.3^{\text {ns }}$ & $2686^{\mathrm{ns}}$ & $12744109^{\mathrm{ns}}$ \\
\hline $\mathrm{S} \times \mathrm{P}$ & 6 & $23.2^{\mathrm{ns}}$ & $134^{\mathrm{ns}}$ & $24.3^{\mathrm{ns}}$ & $337^{\mathrm{ns}}$ & $346^{\mathrm{ns}}$ & $2316844 * *$ \\
\hline erro b & 27 & 14.1 & 80.9 & 31.4 & 27.4 & 18.7 & 233093 \\
\hline $\mathrm{CVa} \%$ & & 4.52 & 4.52 & 23.0 & 5.84 & 11.6 & 9.43 \\
\hline $\mathrm{CVb} \%$ & & 3.25 & 3.25 & 25.3 & 7.95 & 6.08 & 10.4 \\
\hline Mean & & 115 & 277 & 22.2 & 65.9 & 71.0 & 4643 \\
\hline
\end{tabular}

ns, *, ** non-significant, significant at 5 and at $1 \%$ respectively by Snedecor's F-test. Base Saturation (Satur), Phosphorus P2O5 (P), Interaction between base saturation and phosphorus levels (S x P).

Fonte: Research data, Laboratory of UFPI, Bom Jesus - PI 
Research, Society and Development, v. 9, n. 11, e83191110389, 2020

(CC BY 4.0) | ISSN 2525-3409 | DOI: http://dx.doi.org/10.33448/rsd-v9i11.10389

Base saturation, both in greenhouse and field, was altered by applying limestone, thereby increasing the availability of soil phosphorus for both evaluated experiments (greenhouse and field) (Figure 2).

Figure 2. Phosphorus behavior in soil with increasing base saturation.
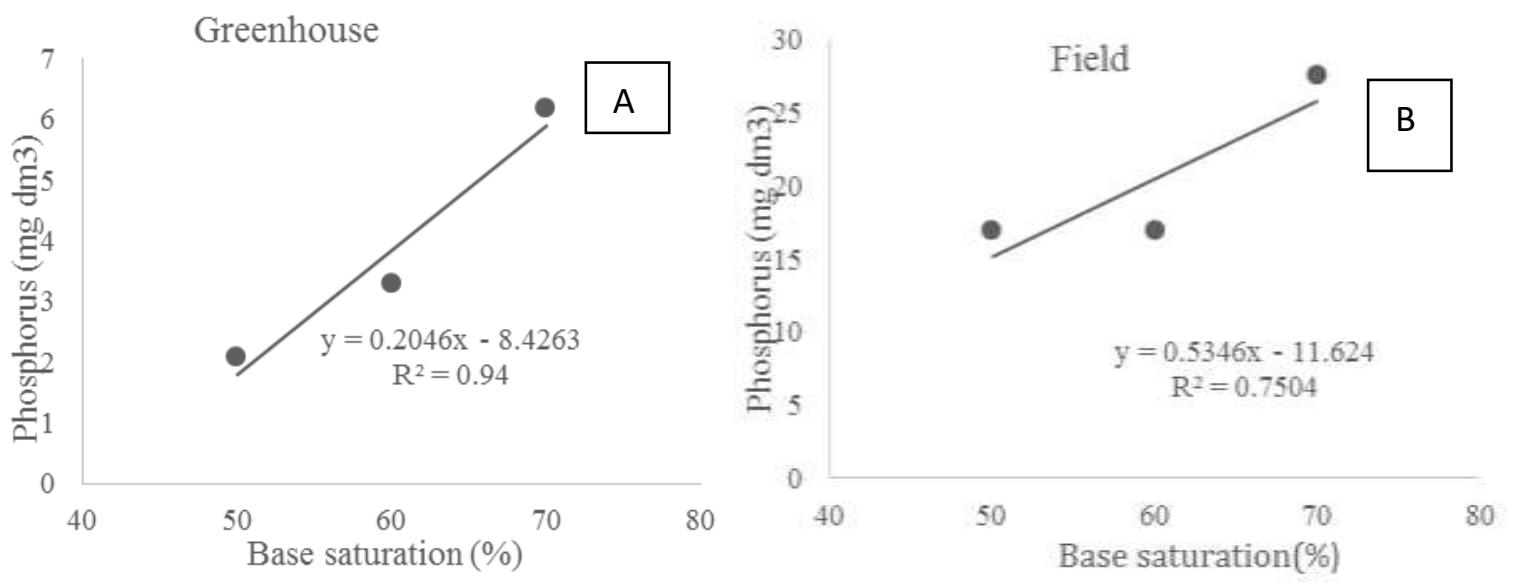

Fonte: Research data, Laboratory of UFPI, Bom Jesus - PI

As for the number of pods per plant, there was no significant interaction for the treatments in the field experiment, but there was difference for the greenhouse experiment (Table 1, Figure 3A). However, the field experiment showed isolated responses to phosphorus levels (Table 1, Figure 3B).

Figure 3. Number of pods per plant for the interaction ( $\mathrm{S} \times \mathrm{P})$ in the greenhouse (Figure 3A) and for the phosphorus levels in the field experiment (Figure 3B).

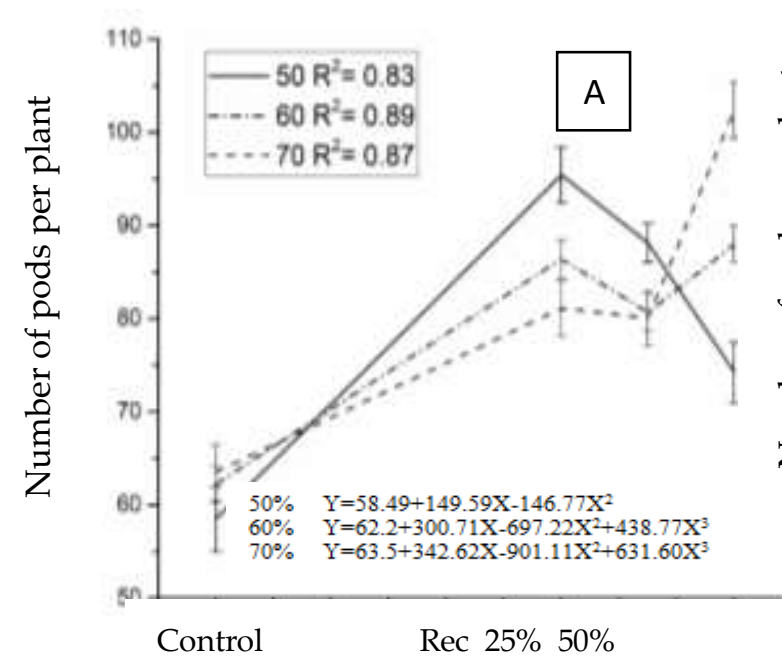

Phosphorus level (g.plot $\left.{ }^{-1}\right)$

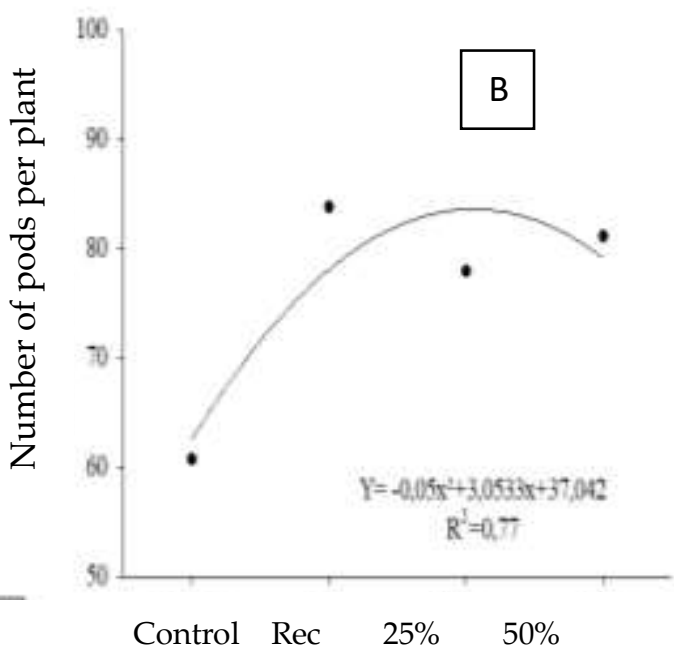

Phosphorus level (g.plot $\left.{ }^{-1}\right)$

Fonte: Research data, Laboratory of UFPI, Bom Jesus - PI. 
In the greenhouse, the phosphorus levels resulted in significant increases for the number of pods per plant. For base saturation 50\%, the best response of phosphate fertilization is at the recommended dose, at which it obtained 96.2 pods per plant. At base saturation $60 \%$, there was no statistical difference between the recommended dose, $25 \%$ and $50 \%$ more than the recommended dose, but were higher than the control. At $70 \%$ saturation, the best dose was the $50 \%$ higher than the recommended, with 102.4 pods per plant (Figure $3 \mathrm{~A})$.

In the field experiment (Figure 3B), the highest results were found at the dose recommended by the analysis, with 88.83 pods per plant. Unlike the greenhouse, the field experiment is influenced by climate change and for this reason the number of pods per plant are lower than that in the greenhouse experiment.

For the number of grains per plant, all levels of phosphorus were superior to the control. For the $50 \%$ base saturation, the best model was the quadratic regression, presenting the greatest number of grains per plant at the recommended dose, yielding 201 grains per plant with $89.62 \%$ more grains compared to the control (Figure 4).

Figure 4. Number of grains per plant for interaction $(\mathrm{S} \times \mathrm{P})$ in the greenhouse experiment.

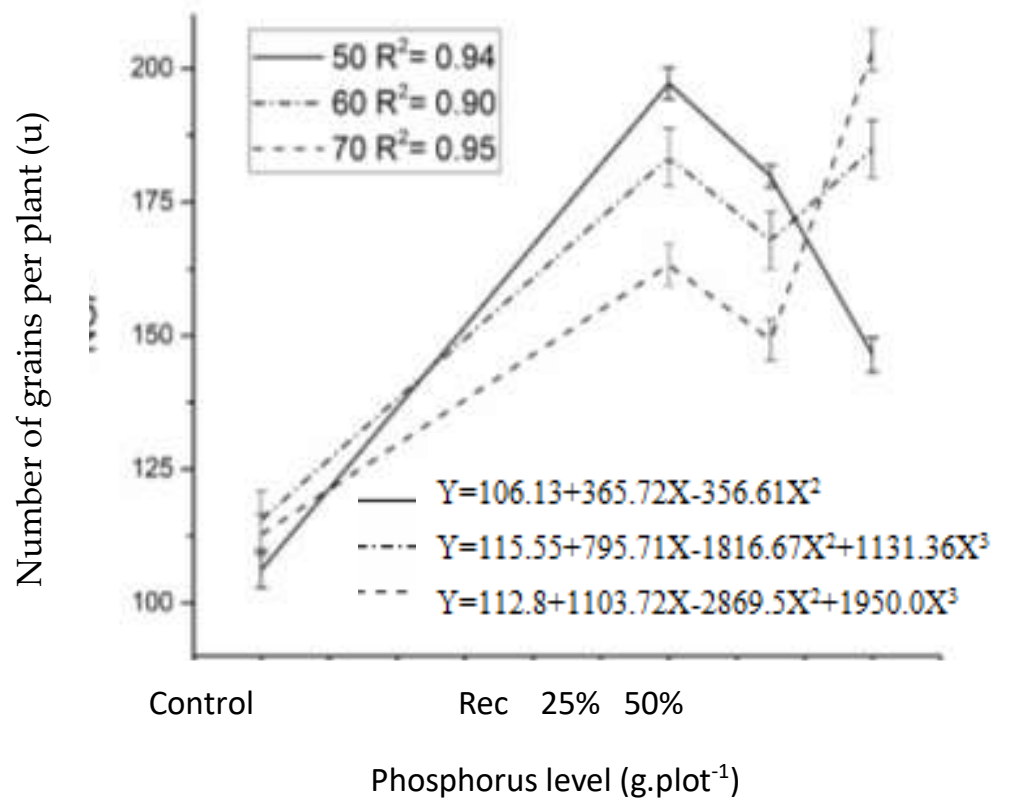

Fonte: Research data, Laboratory of UFPI, Bom Jesus - PI.

For $60 \%$ base saturation, there were no significant results for the recommended doses, $25 \%$ and $50 \%$ more than the recommended dose, however, these results were superior to the control. For $70 \%$ base saturation, the highest number of grains per plant is at the dose $50 \%$ 
more than the recommended, with a yield of 203 grains per plant with $79.64 \%$ more grains compared to the control.

For the first pod height (A1V), there was statistical difference only for the Base saturation in the field experiment (Figure 5) and none of the factors were significant for the greenhouse experiment.

Figure 5. First pod height in response to increased base saturation in the field experiment.

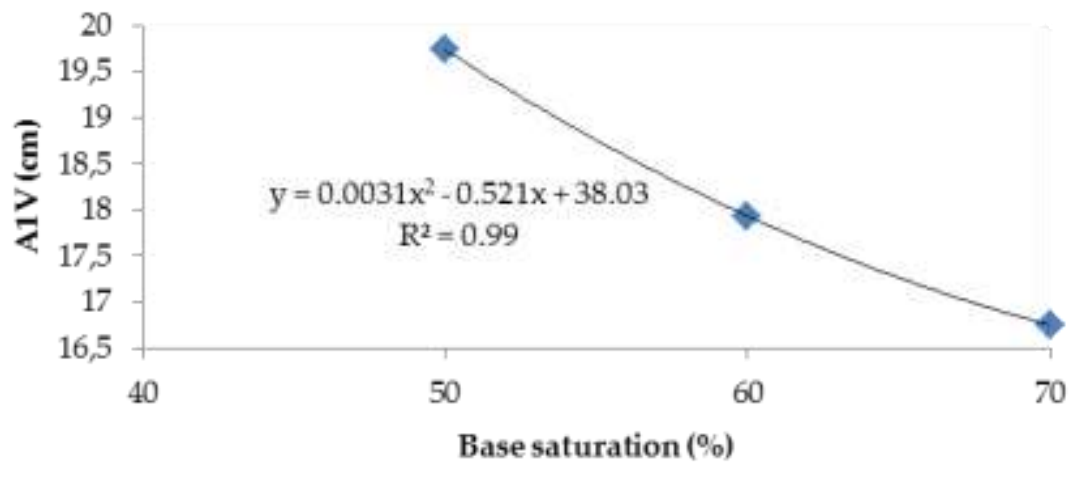

Fonte: Research data, Laboratory of UFPI, Bom Jesus - PI.

The first pod height is inversely proportional to the base saturation, that is, as the base saturation increases, the first pod height decreases (Figure 5).

For the number of grains per pod and one thousand grain weight, there was no significant difference in both experiments for the phosphorus levels and limestone doses applied (base saturation), presenting averages between 2.6 and 2.8 for number of grains per pod and 111.7 and $118.26 \mathrm{~g}$ for one thousand grain weight, respectively.

For both experiments (greenhouse and field), there was a statistically significant difference for the interaction (S X P) (Table 3). For the greenhouse experiment, there was an increase in grain yield according to phosphorus levels at different base saturations and the best yield response occurred at the recommended dose and 50\% more than the recommended dose with a yield of 5860 and $5680 \mathrm{~kg} \cdot \mathrm{ha}^{-1}$, respectively. At $60 \%$ base saturation, the yield behaved linearly with the highest yield at the dose 50\% higher than the recommended with a yield of $4820 \mathrm{~kg} \cdot \mathrm{ha}^{-1}$ (Figure 6A). 
Figure 6. Yield according to phosphorus levels for the different base saturation in the greenhouse (Figure $6 \mathrm{~A}$ ) and field (Figure $6 \mathrm{~B}$ ) experiments.

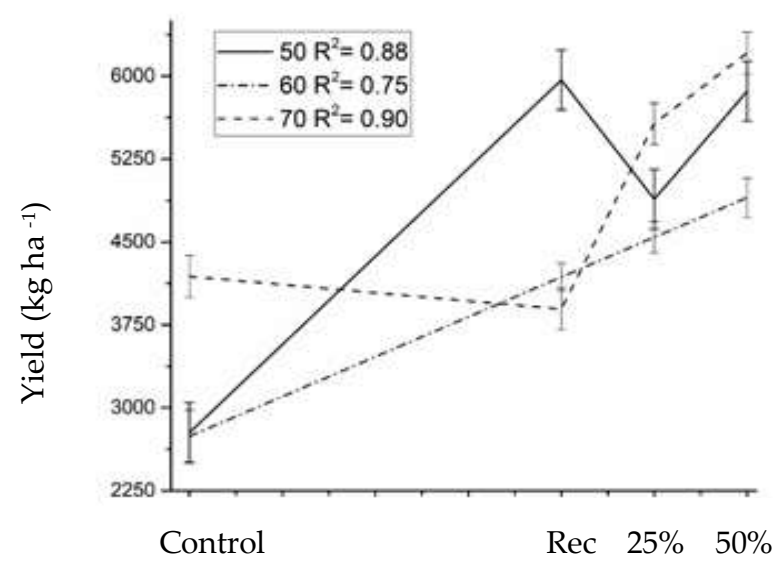

Phosphorus level (g.plot $\left.{ }^{-1}\right)$

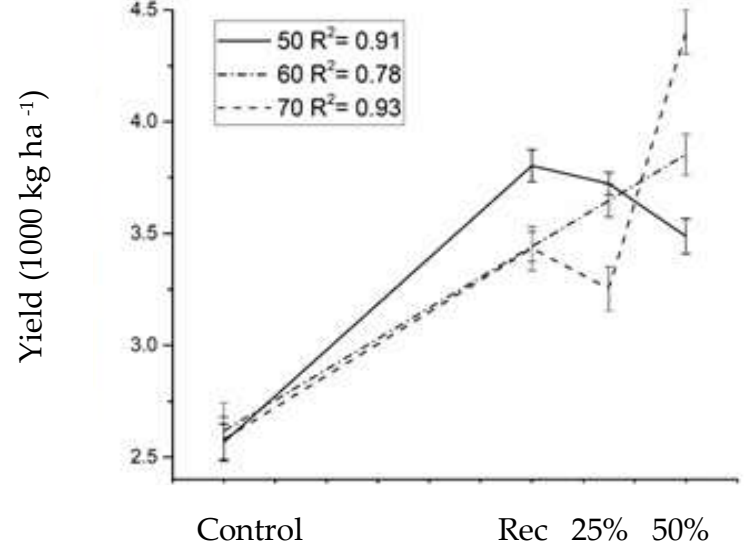

Phosphorus level (g.plot $\left.{ }^{-1}\right)$

\begin{tabular}{ll}
\hline $50 \%$ & $Y_{A}=2775.8+6971.7 x-2478.3 x^{2}+233.7 x^{3}$ \\
$60 \%$ & $Y_{A}=2741.8+360.1 x$ \\
$70 \%$ & $Y_{A}=4188.3-4372.8 x+1654.4 x^{2}-144.9 x^{3}$
\end{tabular}

\begin{tabular}{ll}
\hline $50 \%$ & $\mathrm{Y}_{\mathrm{B}}=2.57+4.13 \mathrm{x}-3.46 \mathrm{x}^{2}$ \\
$60 \%$ & $\mathrm{Y}_{\mathrm{B}}=2.62+1.37 \mathrm{x}$ \\
$70 \%$ & $\mathrm{Y}_{\mathrm{B}}=2.58+20.0 \mathrm{x}-52.96 \mathrm{x}^{2}+36.64 \mathrm{x}^{3}$
\end{tabular}

Fonte: Research data, Laboratory of UFPI, Bom Jesus - PI.

For the field experimente, there was an increase in grain yield as a function of phosphorus levels at different base saturations and the best yield response was found with the dose $50 \%$ more than the recommended at $70 \%$ base saturation. For $50 \%$ base saturation, the best dose was the recommended one, with a yield of $3860 \mathrm{~kg} \cdot \mathrm{ha}^{-1}$ and for $60 \%$ base saturation, the yield growth was linear and its highest yield was found with the dose 50\% more than recommended with a yield of $3800 \mathrm{~kg} \cdot \mathrm{ha}^{-1}$.

In order to better understand the interaction between soybean yield components, we corrected the number of pods per plant (NVP), number of grains per plant (NGP), first pod height (A1V), number of grains per pod (NGV), one thousand grain weight (PMG) and yield (PROD) for both experiments (Table 4). 
(CC BY 4.0) | ISSN 2525-3409 | DOI: http://dx.doi.org/10.33448/rsd-v9i11.10389

Table 4. Correlations between the variables: number of pods per plant (NVP), number of grains per plant (NGP), first pod height (A1V), number of grains per pod (NGV), one thousand grain weight (PMG) and Yield (PROD) for both experiments.

\begin{tabular}{|c|c|c|c|c|c|c|}
\hline \multicolumn{7}{|c|}{ Greenhouse } \\
\hline & NVP & NGP & A1V & $\mathrm{NGV}$ & $\mathrm{PMG}$ & PROD \\
\hline NGP & $0.906^{* *}$ & & & & & \\
\hline A1V & $-0.005^{\mathrm{ns}}$ & $-0.016^{\mathrm{ns}}$ & & & & \\
\hline NGV & $0.197^{\mathrm{ns}}$ & $0.248^{\mathrm{ns}}$ & $-0.172^{\mathrm{ns}}$ & & & \\
\hline PMG & $0.030^{\mathrm{ns}}$ & $0.129^{\mathrm{ns}}$ & $0.237^{\mathrm{ns}}$ & $-0.051^{\mathrm{ns}}$ & & \\
\hline PROD & $0.912^{* *}$ & $0.914^{* *}$ & $0.049^{\mathrm{ns}}$ & $0.217^{\mathrm{ns}}$ & $0.273^{\mathrm{ns}}$ & \\
\hline $\mathrm{CE}$ & $0.064^{\mathrm{ns}}$ & $0.025^{\mathrm{ns}}$ & $0.042^{\mathrm{ns}}$ & $0.132^{\mathrm{ns}}$ & $-0.068^{\mathrm{ns}}$ & $0.109^{\mathrm{ns}}$ \\
\hline \multicolumn{7}{|c|}{ Field } \\
\hline & NVP & NGP & A1V & NGV & PMG & PROD \\
\hline NGP & $1.00^{* * *}$ & & & & & \\
\hline A1V & $-0.14^{\mathrm{ns}}$ & $-0.19^{\mathrm{ns}}$ & & & & \\
\hline NGV & $0.16^{\mathrm{ns}}$ & $0.16^{\mathrm{ns}}$ & $-0.18^{\mathrm{ns}}$ & & & \\
\hline PMG & $0.10^{\mathrm{ns}}$ & $0.27^{*}$ & $0.16^{\mathrm{ns}}$ & $-0.05^{\mathrm{ns}}$ & & \\
\hline PROD & $0.30^{*}$ & $0.58^{* *}$ & $-0.09^{\mathrm{ns}}$ & $0.16^{\mathrm{ns}}$ & $0.86^{* *}$ & \\
\hline $\mathrm{CE}$ & $-0.12 \mathrm{~ns}$ & $-0.02^{\mathrm{ns}}$ & $-0.09^{\mathrm{ns}}$ & $0.03^{\mathrm{ns}}$ & $0.01^{\mathrm{ns}}$ & $0.02^{\mathrm{ns}}$ \\
\hline
\end{tabular}

ns $, *, * *$ non-significant, significant at 5 and $1 \%$ by F-test.

Fonte: Research data, Laboratory of UFPI, Bom Jesus - PI.

In the greenhouse, there was a highly positive correlation between some variables. Significant values are in the correlation between NVP and NGP variables with 0.906; between NVP and PROD with 0.912; and NGP and PROD with 0.914. These values, besides being statistically significant, represent that the obtained samples are in fact an estimate of the true value of the population correlation. There is no linear correlation between the other variables.

Similar to the greenhouse, there was a significant positive correlation between the variables NVP and NGP with 1.00; between NVP and PROD with 0.30; between NGP and PMG with 0.27; between NGP and PROD with 0.58; and between PMG and PROD with 0.86. In the greenhouse experiment, there were more variables with positive correlation than in the field experiment, most of them correlated with yield. This is important because knowing these correlations can estimate soybean yield and production for both environments studied. 


\section{Agronomic Efficiency}

To compare the phosphorus levels as to production, the Agronomic Efficiency (EA) was calculated for the two experiments (Table 5) in the different base saturation, which is the ration of the total biomass to the amount of nutrient absorbed (Viviane et al., 2010). For the greenhouse experiment at $50 \%$ base saturation, it was observed that the control (without phosphorus application) was $2560 \mathrm{~kg} \mathrm{ha}^{-1}$ and the recommended dose was $3640 \mathrm{~kg} \mathrm{ha}^{-1}$ and the agronomic efficiency for this dose was $9 \mathrm{~kg}$ soybeans per kilogram of phosphorus applied, the highest in relation to the others of the same saturation. For the same saturation, in the field experiment, the control was $2776 \mathrm{~kg} \mathrm{ha}^{-1}$ and the dose $25 \%$ above the recommended (1.25) with $4965 \mathrm{~kg} \mathrm{ha}^{-1}$; this agronomic efficiency was $14.59 \mathrm{~kg}$ soybeans per kilogram of phosphorus applied, this is the highest EA in this study. 
Research, Society and Development, v. 9, n. 11, e83191110389, 2020

(CC BY 4.0) | ISSN 2525-3409 | DOI: http://dx.doi.org/10.33448/rsd-v9i11.10389

Table 5. Agronomic efficiency of phosphorus in soybean crop. Greenhouse and field experiments at different base saturation. Bom Jesus, 2017.

\begin{tabular}{|c|c|c|c|c|}
\hline & \multicolumn{2}{|r|}{ Greenhouse } & \multicolumn{2}{|r|}{ Field } \\
\hline & \multicolumn{4}{|c|}{ 50\% Saturation } \\
\hline Treatments & PROD & Agronomic Efficiency & PROD & Agronomic Efficiency \\
\hline P2O5 Levels & $\left(\mathrm{kg} \cdot \mathrm{ha}^{-1}\right)$ & $\mathrm{kg}$ grains/kg P & $\left(\mathrm{kg} \cdot \mathrm{ha}^{-1}\right)$ & $\mathrm{kg}$ grains/kg P \\
\hline Test & 2.560 & 0 & 2776 & 0 \\
\hline Recom (1.0) & 3.640 & 9 & 3887 & 9.26 \\
\hline 1.25 & 3.860 & 8.67 & 4965 & 14.59 \\
\hline 1.5 & 3.520 & 5.33 & 4862 & 11.59 \\
\hline \multicolumn{5}{|c|}{$60 \%$ Saturation } \\
\hline Treatments & PROD & Agronomic Efficiency & PROD & Agronomic Efficiency \\
\hline P2O5 Levels & $\left(\mathrm{kg} \cdot \mathrm{ha}^{-1}\right)$ & $\mathrm{kg}$ grains $/ \mathrm{kg} \mathrm{P}$ & $\left(\mathrm{kg} \cdot \mathrm{ha}^{-1}\right)$ & $\mathrm{kg}$ grains $/ \mathrm{kg} \mathrm{P}$ \\
\hline Test & 2.560 & 0 & 2753 & 0 \\
\hline Recom (1.0) & 3.660 & 9.17 & 3282 & 4.41 \\
\hline 1.25 & 3.540 & 6.53 & 3273 & 3.47 \\
\hline 1.5 & 3.800 & 6.89 & 4059 & 7.25 \\
\hline \multicolumn{5}{|c|}{$70 \%$ Saturation } \\
\hline Treatments & PROD & Agronomic Efficiency & PROD & Agronomic Efficiency \\
\hline P2O5 Levels & $\left(\mathrm{kg} \cdot \mathrm{ha}^{-1}\right)$ & $\mathrm{kg}$ grains/kg P & $\left(\mathrm{kg} \cdot \mathrm{ha}^{-1}\right)$ & kg grains/kg P \\
\hline Test & 2.580 & 0 & 2893 & 0 \\
\hline Recom (1.0) & 3.430 & 7.08 & 3188 & 2.46 \\
\hline 1.25 & 3.250 & 4.47 & 4570 & 11.18 \\
\hline 1.5 & 4.400 & 10.11 & 5209 & 12.87 \\
\hline
\end{tabular}

Fonte: Research data, Laboratory of UFPI, Bom Jesus - PI.

For the greenhouse experiment at $60 \%$ base saturation, the control (without phosphorus application) was $2560 \mathrm{~kg} \mathrm{ha}^{-1}$ and the recommended dose was $3660 \mathrm{~kg} \mathrm{ha}^{-1}$ and the agronomic efficiency for this dose was $9.17 \mathrm{~kg}$ soybeans per kilogram phosphorus applied, the highest in relation to the others of the same saturation. For the same saturation, in the field experiment, the control was $2753 \mathrm{~kg} \mathrm{ha}^{-1}$ and the dose $50 \%$ above the recommended (1.5) was $4059 \mathrm{~kg} \mathrm{ha}^{-1}$, the agronomic efficiency was $7.25 \mathrm{~kg}$ soybeans per kilogram phosphorus applied; this EA was the greatest of this base saturation.

For the greenhouse experiment at $70 \%$ base saturation, the soybean yield without the addition of phosphorus was $2580 \mathrm{~kg} \mathrm{ha}^{-1}$ and with the application of phosphorus at a dose of 
$50 \%$ higher than recommended, the yield increased to $4400 \mathrm{~kg} \mathrm{ha}^{-1}$, with an agronomic efficiency of $10.11 \mathrm{~kg}$ soybeans per kilogram phosphorus applied. For the field experiment, the soybean yield without the addition of phosphorus was $2893 \mathrm{~kg} \mathrm{ha}^{-1}$ and with the application of phosphorus at a dose of $50 \%$ higher than recommended, the yield increased to $5209 \mathrm{~kg} \mathrm{ha}^{-1}$ and presented an agronomic efficiency of $12.87 \mathrm{~kg}$ soybeans per kilogram phosphorus applied.

\section{Discussion}

Limestone application increased the base saturation and this in turn increased the availability of phosphorus in the soil for the two evaluated experiments (field and greenhouse). Examining Figures 2A and B, it can be seen that the level of phosphorus at 70\% base saturation has almost doubled compared to the $50 \%$ base saturation. This is because limestone contributes to the efficiency of phosphate fertilization (Viviani et al., 2010). And consequently, contributes to increased yield.

For both experiments evaluated, levels of phosphorus and limestone applied did not promote significant responses in the first pod height. There was no significant regression at the 5\% probability level, however, the average first pod height found in this study ranged from 16.4 to $19.1 \mathrm{~cm}$, values considered above the recommended for mechanical harvesting. The first pod height considered as suitable for mechanized harvesting is between 10 and $15 \mathrm{~cm}$ (Mauad et al., 2010).

The lack of effect of phosphorus levels for this component may be related to the fact that phosphorus is required throughout the crop cycle, however, 60\% is absorbed after flowering, when the first pod height has already been defined, thus most of the time there was no influence of phosphorus levels on this variable (Rezende et al., 2005).

The variable one thousand grain weight showed no significant difference for the phosphorus levels and limestone applied in both experiments, with averages between 111.7 and $118.26 \mathrm{~g}$ for the field experiment and 110.15 and $116.8 \mathrm{~g}$ for the greenhouse experiment. The results found in this study differ from the results presented by (Marin et al., 2015), who found that the phosphorus supply contributes to the increase in seed mass, with a positive effect of phosphate fertilization.

Although the treatments were not statistically significant, this is a component of fundamental importance, as it contributes to the increase in crop yield (Moterle et al., 2009), 
since the weight of a thousand grains gives an idea of the size, state of maturity and health of the grains (Brasil, 2009).

For the field experiment, the quadratic regression model best described the effect of phosphorus levels on the number of grains per plant (Figure 3). The level that resulted in the highest number of grains per plant was the dose recommended by soil analysis, with a yield of 175 grains per plant, with $65 \%$ more grains than the control. The effects of phosphorus levels allowed a better development of the soybean plant and thus favored the grain yield per plant.

For the greenhouse experiment, the number of grains per plant showed significant results for phosphorus levels and limestone doses, but there was no significant interaction between treatments. As in the field experiment, the quadratic regression model best represented the results for phosphorus levels and limestone doses (Figure 4 A, B). The phosphorus level of $50 \%$ above the recommended dose resulted in the highest number of grains per plant (Figure 4A), with 36\% more grains in relation to the control. These results may be related to the phosphorus distribution in the soil profile, which provided better uptake of this nutrient by the plant. These results are directly related to increased soybean yield.

The application of limestone contributed to a better result in the number of grains per plant, the base saturation values of 60 and $70 \%$ presented the best results, as shown in figure 4B. This may be justified by the fact that liming provides greater availability of soil nutrients.

For the number of pods per plant, there was no significant interaction for the treatments for both experiments. Nevertheless, the greenhouse experiment showed isolated responses for the phosphorus levels and limestone doses applied. And for the field experiment, only the phosphorus levels obtained a significant response.

The number of pods per plant increased quadratically with the phosphorus levels in both experiments (Figure 5 and $6 \mathrm{~B}$ ), showing a linear response only for the greenhouse experiment for the base saturation evaluated (Figure $6 \mathrm{~A}$ ).

In the field experiment, the highest results were found at the dose recommended by the analysis, with 88.83 pods per plant. And for the greenhouse experiment, the maximum yield was found at a dose of $50 \%$ above the recommended by the analysis, with 24.84 pods per plant. The results may be because phosphorus levels combined with soil equilibrium allowed roots to have developed better, contributing to plant development, and thus reflecting the higher number of pods per plant. This is one of the components that most contributes to the grain yield in soybean crops, since it has the highest correlations with production (Zandona et al., 2015). Therefore, when seeking yield increases, attention should be paid to this component. 
Limestone doses positively influenced the number of pods per plant, as observed in Figure 6 A. This may have been due to the fact that limestone increased soil base saturation, and in a greenhouse, some conditions were better controlled, including rainfall, more homogeneous soil, as soybean plants were in pots and this favors the best reaction of limestone and phosphorus absorption by plants.

Phosphorus levels showed significant increases in the number of pods per plant in both experiments (Figures 5 and 6 B). This is because production components are influenced by phosphate and potassium fertilizers, and in soybean crop, $\mathrm{P}$ deficiency decreases yield potential by lower production of flowers and pods (Oliveira Junior et al., 2011). The results of these studies are promising as they positively reflect the final yield of soybean crop.

The quadratic regression model best described the effects of phosphorus levels on soybean yield for the field experiment (Figure 7), which was not related to the base saturation values. The phosphorus level that presented the best results was the recommended dose by soil analysis with a yield of $4858 \mathrm{~kg} / \mathrm{ha}^{-1}$.

High levels of phosphorus provide higher yields of soybeans, with greater likelihood of nitrogen fixation due to greater nodulation stimulation (Araújo et al., 2005). This is because the nitrogen response is directly proportional to phosphorus fertilization (Novais and Smyth, 1999).

For the greenhouse experiment, there was an increase in soybean grain production as a function of base saturation and higher phosphorus availability in the soil, with higher grain yield at a dose of $50 \%$ above the recommended by soil analysis, with $4104 \mathrm{~kg} \mathrm{ha}^{-1}$ (Figure 8 B). And $70 \%$ base saturation provided the highest grain yield, $3503 \mathrm{~kg} \mathrm{ha}^{-1}$, while $50 \%$ base saturation yielded the lowest value, $2771 \mathrm{~kg} / \mathrm{ha}^{-1}$ (Figure $8 \mathrm{~A}$ ). These results of base saturation are because limestone provides soil phosphorus (França Neto et al., 2016). And just as in the other variables, the base saturation was significant only in the greenhouse experiment, this may have occurred due to the cultivation in pots, under favorable conditions for plant development, as well as the controlled conditions provided by the protected cultivation.

The high yield results found in these studies may also be justified by the fact that very high doses of $\mathrm{P}$ respond positively in soils with low content of available phosphorus (Schlindwein an Gianello, 2005) and according to the soil analyses (tables 03 and 04), phosphorus values are considered low and very low for annual crops, and the crop response to fertilizer use depends among other factors on soil fertility status, that is, low fertility soils have a high probability of response to nutrient use (Alcântara Neto et al., 2010). 
The results presented in this study are similar to those reported by (Rosolem and Tavares, 2006) in an experiment conducted in soybean pots; the authors found a significant difference in yield between treatments with and without phosphorus. (Valadão Junior et al., 2008) also working with phosphorus in an experimental area observed positive effect of phosphorus levels on soybean grain yield.

To analyze the influence of phosphorus levels on yield, the Agronomic Efficiency was calculated for both experiments, which is the ratio of total biomass to amount of nutrient absorbed (Fageria, 1998). For the field experiment, the estimated yield of soybean grains observed in the treatment without the addition of phosphorus was $3094 \mathrm{~kg} \mathrm{ha}^{-1}$ and as phosphorus was added at the recommended dose by soil analysis, the yield increased to 4858 $\mathrm{kg} \mathrm{ha}^{-1}$ and the agronomic efficiency for this dose was $14.7 \mathrm{~kg}$ soybeans per kilogram phosphorus applied. At the dose $25 \%$ above the recommended, the yield was $4298 \mathrm{~kg} \mathrm{ha}^{-1}$ and the agronomic efficiency was $8.02 \mathrm{~kg}$ soybeans per kilogram phosphorus applied, while for the dose $50 \%$ above the recommended, the yield was $4677 \mathrm{~kg} \mathrm{ha}^{-1}$ and the agronomic efficiency was $8.79 \mathrm{~kg}$ soybeans per kilogram phosphorus applied. For the field experiment, the phosphorus level recommended by soil analysis showed the highest yield and the best agronomic efficiency with $14.7 \mathrm{~kg}$ soybeans per kilogram phosphorus applied.

For the greenhouse experiment, the soybean yield without the addition of phosphorus was $1438 \mathrm{~kg} \mathrm{ha}^{-1}$ and with the application of phosphorus at the recommended dose, the yield increased to $3404 \mathrm{~kg} \mathrm{ha}^{-1}$ and presented an agronomic efficiency of $16.38 \mathrm{~kg}$ soybeans per kilogram phosphorus applied. For the dose $25 \%$ above the recommended, the yield was 4034 $\mathrm{kg} \mathrm{ha}{ }^{-1}$, and the agronomic efficiency was $17.30 \mathrm{~kg}$ soybeans per kilogram phosphorus applied, while for the dose 50\% above the recommended, the yield was $4104 \mathrm{~kg} \mathrm{ha}^{-1}$ and the agronomic efficiency was only $14.81 \mathrm{~kg}$ soybeans per kilogram phosphorus applied.

The results for the greenhouse experiment showed different behaviors than the field results, because the highest yield found in the greenhouse was observed at the dose $50 \%$, but the best agronomic efficiency was observed at the dose $25 \%$, with production of $17.30 \mathrm{~kg}$ soybeans per kilogram phosphorus applied. A higher level of the nutrient increased yield, however nutrient decreased its efficiency. Because of this, agronomic efficiency can also be called economic efficiency (Fageria, 1998)]. What should be observed is the level that provides the maximum economic return for the fertilizer applied, thus providing higher yield with lower production costs.

Similar results were found by (Fageria et al., 2014), who worked with rice cultivation and found that phosphorus efficiency influenced grain yield and (Dobermann et al., 2000), 
working with rice cultivation, verified that the agronomic efficiency of nitrogen was $20 \mathrm{~kg}$ grains per kilogram nitrogen applied. Likewise, (Fageria et al., 2007) reported that agronomic efficiency of nitrogen was $19 \mathrm{~kg}$ rice grains per kilogram nitrogen applied.

Studying the efficiency of phosphorus is important to indicate to the producer which is the best management. This is because soybean is a crop dependent on phosphorus, which is an element of photosynthesis and the agronomic efficiency of this nutrient provides a solid basis for improving soybean crop yield (AO et al., 2014).

\section{Conclusions}

Phosphorus fertilization increases soybean grain yield.

The dose of $50 \%$ higher than the recommended at $70 \%$ base saturation obtained higher yield component gains and consequently higher yield in soybean crop.

The agronomic efficiency of phosphorus in the Brazilian Cerrado soils is $14.59 \mathrm{~kg}$ in $50 \%$ base saturation soils and $12.87 \mathrm{~kg}$ soybeans per kilogram phosphorus applied at $70 \%$ base saturation.

Knowing that the cerrado has different types of soils with very varied saturates, it is necessary to continue research including not only the application of phosphors but also of other nutrients to see their interaction with the different base saturations

\section{References}

Alcântara Neto, F., Gravina, G. A., Souza, N. O. S., \& Bezerra, A. A. C. (2010). Phosphorus fertilization in the soybean crop at the micro region of Alto Médio Gurguéia. Revista Ciências Agronômicas, 41 (2), 266-271.

Alcântara Neto, F., Petter, F. A., Pavan, B.E., Schmit, C. R., Almeida, F. A., Pacheco, L. P., \& Piauilino, A. C. (2012). Desempenho agronômico de cultivares de soja em duas épocas de semeadura no cerrado piauiense. Comunicata Scientiae, 3, 215-219.

Amaral, L. A., Ascari, J. P., Duarte, W. M., Mendes, I. R. N., Santos, E. S., Julio, \& O. L. L. (2017). Effect of doses of agricultural plaster on corn crop and chemical changes in the soil. Revista Agrarian, 10:31-41. 
AO, X., Guo, X. J., Zhu, Q., Zhang, H. J., Wang, H. Y., MA, Z. H., Han, X. R., Zhao, M. H., \& Xie, F. T. (2014). Effect of Phosphorus Fertilization to P Uptake and Dry Matter Accumulation in Soybean with Different P Efficiencies. Journal of Integrative Agriculture, 13(2), 326-334.

Araújo, W. F., Sampaio, R. A., \& Medeiros, R. D. (2005). Resposta de cultivares de soja à adubação fosfatada. Revista Ciências Agronomicas, 36,129-134.

Bambolim, A.; Caione, G., Souza, N. F., Seben-Junior, G. F., \& Ferbonink, G. F. (2015). Calcário líquido e calcário convencional na correção da acidez do solo. Revista de Agricultura Neotropical, 2(3), 34-38.

Barbosa, G. F., Centurion, M. A. P. C., \& Ferraudo, A. S. (2014). Potencial do manejo integrado da ferrugem asiática da soja: severidade da doença, desenvolvimento vegetativo e componentes da produção, cultivar MG/BR-46 (Conquista). Bioscience Journal, 30(3), 76-89.

Brasil (2009). Ministério da Agricultura, Pecuária e Abastecimento. Regras para análise de sementes. Brasília: Mapa/ACS, 399 p.

Broch, D. L., \& Ranno, S. K. (2012). Fertilização do solo, adubação e nutrição da cultura da soja. Fundação MS. Tecnologia e Produção: Soja e Milho, 2011/2012. Recuperado de http://www.fundacaoms.org.br/base/www/fundacaoms.org.br/media/attachments/142/142/ne warchive-142.pdf

Chien, S. H., Menon, R. G. (1995). Factors affecting the agronomic effectiveness of phosphate rock for direct application. Fertilizer Research, 41, 227-234.

Dalchiavon, F. C., Carvalho, M. P. (2012). Correlação linear e espacial dos componentes de produção e produtividade da soja. Semina: ciências agrárias, 33, 541-552.

Dall'Agnol, A. (2016). Embrapa Soy in the context of soybean development in Brazil: history and contributions. Embrapa: Brasília, DF, Brasil, 72p. 
Dobermann, A., Dawe, D., Roetter, R. P., \& Cassman, K. G. (2000). Reversal of rice yield decline in a long-term continuous cropping experiment. Agronomy Journal, 92, 633-643.

Fageria, N. K. (2001). Efeito da calagem na produção de arroz, feijão, milho e soja em solo de cerrado. Pesquisa agropecuaria brasileira, 36(11), 1419-1424.

Fageria, N. K. (1998). Otimização da eficiência nutricional na produção das culturas. Revista Brasileira de Engenharia e Agrícultra Ambiental, 2, 6-16.

Fageria, N. K., Moreira, A., Moraes, L. A. C., \& Moraes, M. F. (2014). Influence of Lime and Gypsum on Yield and Yield Components of Soybean and Changes in Soil Chemical Properties. Communications in Soil. Science and Plant Analysis. 45, 271-283.

Fageria, NK, AB Santos, VA Cutrim (2007). Produtividade de arroz irrigado e eficiência de uso do nitrogênio influenciadas pela fertilização nitrogenada. Pesquisa Agropecuaria brasileira, 42, 1029-1034.

FAO (2016). Food and Agriculture Organization of the United Nations. Recuperado de http://faostat3. fao.org/browse/Q/QC/E.

França Neto, J. B., Krzyzanowski, F. C., Henning, A. A., Pádua, G. P., Lorini, I., \& Henning, F. A. (2016). Tecnologia da produção de semente de soja de alta qualidade. Embrapa: Londrina, Brasil, 82 p.

Loman, A. A., \& Ju, L. K. (2017). Enzyme-based processing of soybean carbohydrate: Recent developments and future prospects. Enzyme and Microbial Technology, 106, 35-47.

Marin, R. S. F., Bahry, C. A., Nardino, M., \& Zimmer, P. D. (2015). Efeito da adubação fosfatada na produção de sementes de soja. Revista Ceres, 62 (3).

Mauad, M., Silva, T. L. B., Almeida Neto, A. I., \& Abreu, V. G, (2010). Influência da densidade de semeadura sobre características agronômicas na cultura da soja. Revista Agrarian, 3, 175-181. 
Moterle, L. M., Santos, R. F., Lucca, B. A., Scapim, C. A., \& Lana, M. C. (2009). Influência da adubação com fósforo e potássio na emergência das plântulas e produtividade da cultura da soja. Revista Ciência Agronomica, 40(2), 256-265.

Novais, R. F., \& Smyth, T. J. (1999). Fósforo em solos e plantas em condições tropicais. UFV: Viçosa, MG, Brasil, 399p.

Oliveira Júnior, A., Prochnow, L. I., \& Klepker, D. (2011). Soybean yield in response to application of phosphate rock associated triple superphosphate. Scientia Agricola, 68, 376385.

Petter, F. A., Pacheco, L. P., Alcantara Neto, F. A., \& Santos, G. G. (2012). Respostas de cultivares de soja à adubação nitrogenada tardia em solos de cerrado. Revista Caatinga, 25, $67-72$.

Rezende, P. M., Gris, C. F., Carvalho, J. G., Gomes, L. L., \& Bottino, L. (2005). Adubação foliar. I. Épocas de aplicação de fósforo na cultura da soja. Ciênc Agrotec. 29(6), 1105-1111.

Rosolem, C. A., \& Tavares, C. A. (2006). Phosphorus deficiency symptoms in soybean. Rev Bras Ciênc 30(2), 385-389.

Schlindwein, J. A., Gianello, C. (2005). Doses de Máxima Eficiência Econômica de fósforo e potássio para culturas cultivadas no sistema de Plantio Direto. Revista Plantio Direto, 85, 2025 .

Silva, R. R., Leite, R. C., Freitas, G. A., Silva, P. S. S., Carneiro, J. S. S. (2015). Phosphate fertilizer efficiency in soybean crop in Bahia. Agropecuaria Cientifica no Semiárido, 11, 1322.

Simpson, R. J., Oberson, A., Culvenor, R. A., Ryan, M. H., Veneklaas, E. J., Lambers, H., Lynch, J. P., Ryan, P. R., Delhaize, E., Smith, F.A., Smith, S. E., Harvey, P. R., \& Richardson, A. E. (2011). Strategies and agronomic interventions to improve the phosphorususe efficiency of farming systems. Plant Soil, 349, 89-120. 
Taiz, L., Zeiger, E., Moller, I. M., \& Murphy, A. (2017). Fisiologia e desenvolvimento vegetal. 6.ed., Artmed: Porto Alegre, Brasil, 888p.

Trevizam, A. R., Silva, M. L. S., \& Muraoka, T. (2013). Distribuição de fósforo do fertilizante na planta de soja e sua exportação pela cultura. Ambiência, 9, 475-486.

Valadão Júnior, D. D., Bergamin, A. C., Venturoso, L. R., Schlindwein, J. A., Caron, B. O., \& Schmidt, D. (2008). Adubação fosfatada na cultura da soja em Rondônia. Scientia Agraria, 9, 369-375.

Viviani, C. A., Marchetti, M. E., Vitorino, A. C. T., Novelin, O. J. O., \& Gonçalves, M. C. (2010). Disponibilidade de fósforo em dois latossolos argilosos e seu acúmulo em plantas de soja, em função do aumento do pH. Ciências agrotec, 34(1), 61-67.

Wang, E., Bell, M., Luo, Z., Moody, P., \& Probert, M. E. (2014). Modelling crop response to phosphorus inputs and phosphorus use efficiency in a crop rotation. Field Crops Research, $155,120-132$.

Zandona, R. R., Beutler, A. N., Burg, G. M., Barreto, C. F., \& Schmidt, M. R. (2015). Gesso e calcário aumentam a produtividade e amenizam o efeito do déficit hídrico em milho e soja. Pesquisa Agropecuaria Tropical, 45, 128-137

\section{Percentage of contribution of each author in the manuscript}

Rosilene de Morais da Silva - 20\%

Antônio Veimar da Silva - 20\%

João Carlos Medeiros - 10\%

Artur Mendes Medeiros - 10\%

Erick Almeida Andrade - 10\%

Carla Michelle da Silva - 10\%

Marina Silveira Batista - 10\%

Fábio Mielezrski - 10\% 